Kolozsi Pál Péter - Lentner Csaba - Parragh Bianka

\title{
Közpénzügyi megújulás és állami modellváltás Magyarországon
}

\section{Renewal of Public Finances and Change of the State Management Model in Hungary}

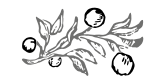

\section{Összefoglalás}

Az állampénzügyek konszolidálása, az állam megerôsítése és a biztos makrogazdasági alapok szükséges feltételei a jól irányított állam kialakításának, hiszen csak egy hatékony és erôs állam képes a magánszektort a tartós együttmúködés felé terelni. A válság előtti években Magyarországot fenntarthatatlan közpénzügyek, elhibázott és fenntarthatatlan költségvetési politika, illetve ebból adódóan gyenge gazdasági fundamentumok jellemezték. Ez szuboptimális állami múködést jelentett, ahol az állam és a gazdasági szereplôk közötti együttmúködés alapjai érdemben sérültek. Az

Dr. Kolozsi Pál Péter, PhD, fóosztályvezetô, Magyar Nemzeti Bank, egyetemi docens, Budapesti Corvinus Egyetem MNB Tanszék, tudományos munkatárs, Nemzeti Közszolgálati Egyetem Közpénzügyi Kutatóintézet (kolozsip@mnb.hu), PRoF. DR. LENTNER Csaba egyetemi tanár, a Nemzeti Közszolgálati Egyetem Közpénzügyi Kutatóintézetének vezetôje, címzetes egyetemi tanár, Szent István Egyetem, egyetemi magántanár, Kaposvári Egyetem (Lentner.Csaba@uni-nke.hu), DR. PARragh Bianka, PhD, a Magyar Nemzeti Bank Monetáris Tanácsának tagja, egyetemi adjunktus, Óbuda Egyetem, tudományos munkatárs, Nemzeti Közszolgálati Egyetem Közpénzügyi Kutatóintézet (parraghb@mnb.hu). 
évtized elejére ezért elengedhetetlenné vált az állami múködés és kiemelten az állampénzügyek megújítása, aminek elsô és az állam múködésének egészét átható lépése a közpénzügyi fejezetet is tartalmazó Alaptörvény elfogadása volt. Az Alaptörvényból, illetve az adósságszabályból levezethetôen került sor a magyar közpénzügyek stabilizálására (a fiskális fordulatra, az önkormányzati konszolidációra, a társadalombiztosítási rendszer reformjára, illetve a közpénzügyi ellenôrzés megújítására), és közvetett módon ehhez kapcsolódik a 2013-ban elkezdett monetáris politikai, valamint az utóbbi években elindított, de részben még elôttünk álló versenyképességi fordulat is. A 2010 óta meghozott állampénzügyi megújulás lehetôvé teszi a magyar állam és a gazdasági szereplôk tartós és hatékony kooperációját, ami megfeleló alapot jelent a jól irányított állam kiépítésére és arra a szemléletváltásra, ami a pozitív ösztönzôket aktívan alkalmazó, az érintettekkel partneri együttmúködésre törekvô állami múködéshez vezethet.

Journal of Economic Literature (JEL) kódok: H03, H21 E02, H83

Kulcsszavak: közpénzügyek, fiskális politika, monetáris politika, intézményrendszer, makroökonómia, gazdasági szereplôk viselkedése, kooperáció, Magyarország

\section{Summary}

Consolidation of public finances, strengthening of the state and sound macroeconomic basis are the preconditions of good governance, as only an efficient and strong state can move the private sector towards lasting cooperation. Before the global financial crisis, Hungary was characterized by unsustainable public finances, flawed and irresponsible fiscal policy, and consequently weak economic fundamentals. This represented a suboptimal state management, where the basics of co-operation between the state and the economic actors were seriously damaged. Therefore, by the beginning of the decade, the renewal of state management and, above all, public finances became essential, the first step of which was the adoption of the Fundamental Law with a chapter focused on public finances. The stabilization of Hungarian public finances (fiscal turnaround, consolidation of local governments, reform of the social security system and renewal of the control of public finances) can be derived from the Fundamental Law and the debt rule, and the reforms concerning monetary policy (from 2013) and competitiveness (launched in recent years, but partly ahead of us) can also be associated with these regulations. The revival of state finances since 2010 permits a lasting and effective co-operation between the Hungarian state and the economic actors. This is an appropriate basis for the creation of a well-managed state and the attitude change potentially leading to a state management actively leveraging positive incentives and seeking partnership with the relevant stakeholders.

Journal of Economic Literature (JEL) codes: H03, H21 E02, H83

Keywords: public finances, fiscal policy, monetary policy, institutional system, macroeconomics, behavior of economic actors, co-operation, Hungary 
Kolozsi Pál Péter - Lentner Csaba - Parragh Bianka: Közpénzügyi megúüulás és...

\section{BEVEZETÉS}

A globális pénzügyi válság ${ }^{1}$ súlyosan érintette Magyarországot, aminek egyik oka a rossz ösztönzőrendszert kialakító, nem megfelelô minőségú állami múködés volt. A magyar gazdaságpolitika a válság elốtti években olyan pályára állt, amit nagy államháztartási hiány, növekvố államadósság és a magánszektor eladósodása, magas adók, nagy adóelkerülés, alacsony foglalkoztatási szint, nem fenntartható növekedés és magas infláció, illetve a devizahitelezés miatt kiemelkedô külsố sérülékenységi kitettség jellemzett. Ez vezetett oda, hogy 2008-ban a magyar állam nem tudta a múködését a piacról finanszírozni, és az Európai Unióban elsôként volt kénytelen nemzetközi hitelcsomagért folyamodni, amit megszorítások és politikai instabilitás kísért.

A magyar állam múködésének megújítása az évtized elejére tehát kulcskérdéssé vált. Olyan állami keretek kialakítása vált szükségessé, amely egy magasabb dinamikájú és egyben fenntartható növekedési pályára állítja a magyar gazdaságot. Ennek alapfeltétele az állami szerepvállalás megerôsödése, konszolidálása, a biztos makrogazdasági alapok megteremtése (fiskális, monetáris és növekedési, illetve elôretekintve versenyképességi fordulat), ami elvezethetett egy olyan állami múködéshez, amely képes érintett partnereit (kiemelten az állampolgárokat és a gazdasági szereplóket) kooperatív magatartás felé orientálni, és ezzel megteremteni egy új közpénzügyi állammodell alapjait.

Tanulmányunk elôször sematikusan bemutatja a kooperatív közpénzügyi állammodell kereteit, és felvázolja, milyen feltételek szükségesek ahhoz, hogy egy ilyen állammodell múködésképes legyen. Ezt követôen vázlatosan összegezzük, hogy jelen évtizedben milyen intézkedések születtek annak érdekében, hogy a magyar állam megerősödjön, és ezzel lehetôvé váljon az állami múködés tartós megújulása. A sikeres és hatékony állam kritériumainak feltárása nemcsak Magyarországon, hanem világszerte a döntéshozók és kutatói közösségek fókuszában van, valamint a kérdés aktualitását mutatja az is, hogy idén Richard Thaler személyében olyan közgazdász kapta a közgazdasági Nobel-díjat, aki kiemelten foglalkozott az állami múködés és az egyéni, illetve társadalmi (közösségi) viselkedés összefüggéseivel. ${ }^{2}$

\section{ELMÉLETI KERET}

Tanulmányunk kiindulópontja és motivációja, hogy nincs egyenrecept a sikeres állami múködés kialakítására, hiszen „nem egy stabil paradigmában, hanem a paradigmaváltások korában élünk”, miközben újra fel kell találnunk a „,ikeres magyar államot” (Orbán, 2017). Jelen írásban arra nem vállalkozunk, hogy kidolgozzuk a sikeres állammúködés receptjét, csak arra teszünk kísérletet, hogy bizonyos aspektusok megvilágításával hozzájáruljunk a sikeres magyar államról való közéleti gondolkodáshoz, támpontokat adjunk az útkereséshez.

Alaptézisünk, hogy az állampolgárokkal, az üzleti szférával, a bankokkal és minden egyéb érintettel (stakeholderek) kooperatív kapcsolatot kiépíteni képes állam sikeresebb lehet, mint az, amely ezt nem tudja elérni. ${ }^{3}$ Ebbôl adódóan, illetve elfogadva, hogy a társadalmi szükségletek magasabb szinten történô kielégítése szükségszerúen 
magával hozza a hatékony partnerség kialakításának igényét, azt a kérdést próbáljuk körüljárni, miképp kerülhet közelebb egy állam ehhez a kooperatív múködéshez. Tanulmányunk az alábbi két feltételezésre épül:

1. Az állami intézkedések hatása nagyban függ a környezeti faktoroktól, melyek közül kiemelkedôen fontos az állam és az érintettek közötti bizalom, kooperáció szintje.

2. Az állam és az érintettek közötti kooperáció megléte és hiánya alapján kialakuló „országállapotot” nagyban meghatározza, hogy az állam képes-e kooperatív viselkedésre ösztönözni az érintett társadalmi csoportokat.

Az állami intézkedések hatásmechanizmusát írja le Mandl-Dierx-Ilzkovitz koncepcionális modellje, amely eredetileg a közpénzügyi célszerúség, eredményesség, hatékonyság és hasznosság összefüggéseit mutatta be, de kiterjeszthetô az állami feladatellátás egészének erôforrás-kimenet-eredmény összefüggéseire is. A kiterjesztett modell kereteit az 1. ábra mutatja be.

\section{1. ábra: Állami intézkedések hatásmechanizmusa}

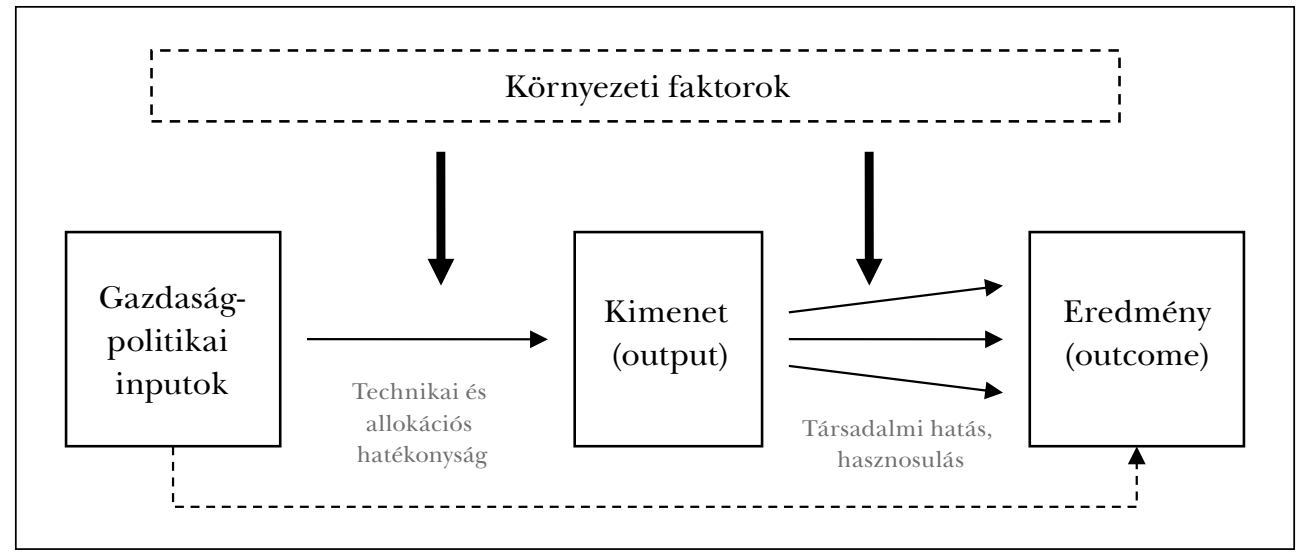

Forrás: Saját szerkesztés

A kiterjesztett modell szerint minden gazdaságpolitikai intézkedés, cselekvés, program (input) egyfajta kimenetet (output) eredményez, amely hosszabb és mélyebb hatásait tekintve valamilyen eredménnyé (outcome) válik. A hatásmechanizmust nagyban meghatározzák a környezeti faktorok is, mint például az adott ország társadalmi-gazdasági háttere, gazdasági környezete, a közszféra általános múködési hatásfoka, valamint idesorolható tanulmányunk fókusztémája, az állam és az érintettek közötti bizalom és kooperáció szintje is. Jelen elemzés a transzmissziós csatornákra fókuszál, és arra keresi a választ, hogy az állam a kooperáció szintjének emelésével miképp tudja biztosítani, hogy az intézkedések a lehetô legjobb kimenetet és eredményt érjék el.

- Miképp biztosítható, hogy az adott állami múködés a megfelelô technikai és allokációs hatékonyságot biztosítva ahhoz az operatív állapothoz érkezzen el, amit célul tûzött ki? 
Kolozsi Pál Péter - Lentner Csaba - Parragh Bianka: Közpénzügyi megújulás és...

- Mi segítheti elô, hogy ennek az adott operatív célállapotnak a társadalmi hatása, hasznosulása megfelelő, a széles értelemben vett társadalmi eredmény pedig optimális legyen?

Tanulmányunk abból indul ki, hogy mind a kimenet, mind az eredmény érdemben javítható azáltal, ha a stakeholderek, ${ }^{4}$ kiemelten a piac és az egyéb állami szereplók

- érdekeltté válnak az állami intézkedések sikerében,

- azonosulnak az állami múködés, adott állami intézkedés, program céljaival,

- elkötelezetté válnak az állami célok tekintetében.

A hatékony állami múködés bizonyos szempontból e fenti „állapot” elérésének felel meg, hiszen ez az állam és a széles értelemben vett érintettek közötti együttmúködést jelenti, ami feltételezésünk szerint hatékonyabb, mint a kooperáció hiányára épülô múködési modell. Mivel a közbizalom erôsítésével kölcsönösen elônyös érdekközösség jöhet létre, így az állami múködés megújításának abba az irányba kell mutatnia, ahol az alapelvek, a célok, a célrendszer és a célstruktúra szintjén, illetve a gyakorlatban is megjelenik a kooperáció, a közbizalom erôsítése, elôsegítve nemcsak a konkrét cselekvés, hanem az állammal szembeni attitûd (gondolkodásmód, szemléletmód, értékrend) változását is.

Tanulmányunk másik feltételezése a kooperatív és a nem kooperatív viselkedések interakciójára vonatkozik. Ebben a keretben a két végletes állammodellt a kooperatív és a nem kooperatív állammodell jelenti. Kooperatív állami viselkedésnek, hozzáállásnak azt tekintjük, ha az állam úgy alakítja ki keretrendszerét és szabályait, hogy az a szabályokat betartó partnerek szempontjából legyen optimális. Nem kooperatív állami megközelítés ezzel szemben az, ha az állami múködést az érintettekkel szembeni bizalmatlanság jellemzi, ezért a tipikus állami szabályozóeszköz a szabályokat betartók túlzott terhelése. A fenti leírások leegyszerúsítôk, amit elsôsorban az magyaráz, hogy a követett állammodell az egyes helyzetekben eltéró módon nyilvánulhat meg, illetve természetesen az egyes állami intézkedések esetében a releváns partnerek köre is eltérô lehet. ${ }^{5}$

Annak függvényében, hogy az állam viselkedésére az érintettek miképp reagálnak, sematikus modellünkben négy országállapot jöhet létre:

- kooperáló állam és kooperáló érintettek: ez a jól irányított állam modellje, amelyben az állam és az érintettek között kölcsönös együttmúködés valósul meg (egy adózási példával élve: az állam alacsony adókat alkalmaz, az adófizetôk oldaláról pedig magas az adótudatosság, az adófizetési hajlandóság);

- kooperáló állam, de nem kooperáló érintettek: az állam támogató jellegú viselkedésére az érintettek nem kooperatív módon reagálnak, azaz gyakorlatilag „kihasználják” az állami viselkedésból adódó mozgásteret (az előzố példával élve: az adók alacsonyak, de nagy az adóelkerülés, a szürkegazdaság aránya);

- nem kooperáló állam, kooperáló érintettek: az elôzó állapot ellentettje, amelyben a társadalom (vélhetôen egy korábbi idôszak állami kooperációjából adódóan) kooperatív, együttmúködô, de az állam nem az (az adópolitikai példával élve: magas az adófizetési hajlandóság és képesség, amire az állam túladóztatással, még több jövedelem elvonásával reagál); 
- nem kooperáló állam és nem kooperáló érintettek: ez a bizalmatlanság állapota, ahol sem az államot, sem a stakeholdereket nem kooperatív viselkedés jellemzi (az állam magas adókulcsokat alkalmaz, az adófizetői attitúd pedig az adóelkerülés) .

Társadalmi szempontból optimálisnak a jól irányított állam állapota tekinthetô, hiszen az együttmúködés mind a kooperáló felek, mind áttételesen a társadalom egésze számára hasznot hoz, hiszen a közbizalom erôsítése és a közjó mint legfelsôbb társadalmi cél megvalósítása irányába mutat. Az is belátható, hogy sem a „társadalmi bázisát felélố állam”, sem pedig a „naiv állam” nem fenntartható (nem egyensúlyi), szemben azzal az állapottal, amikor sem az állam, sem az érintettek nem kooperatívak, ez ugyanis szintén egyensúlyi állapot lehet, hiszen kizárólag saját viselkedésének megváltoztatásával senki sem képes a saját helyzetén javítani. A két egyensúlyi állapot közötti átmenet ugyanakkor nem triviális: a fó kérdés az, hogy az állam kooperatív magatartására mi lesz az érintettek reakciója.

\section{1. táblázat: Az állam és a stakeholderek kooperációs mátrixa}

\begin{tabular}{l|l|l}
\hline & Kooperáló partnerek & Nem kooperáló partnerek \\
\hline Kooperáló állam & „Jól irányított, ösztönzó állam” & „Naiv, kihasznált állam” \\
\hline Nem kooperáló állam & „Társadalmi bázisát felélő állam” & „Nem kooperáló, büntetô állam” \\
\hline
\end{tabular}

Forrás: Saját szerkesztés

A mátrix jobb alsó sarkát jelentô szuboptimális pozícióból csak abban az esetben lehet eljutni a Pareto-optimumot jelentố bal felsố sarokba, ha az állami kooperáció az érintett partnerek részéról is kooperálással találkozik (1. táblázat). Ez azt jelenti: a kooperáló állami modell eléréséhez az szükséges, hogy az állam biztos lehessen benne, kooperatív lépéseire együttmúködố támogatás lesz a válasz, nem pedig a korábbi nem kooperatív magatartás folytatása. ${ }^{6}$ Ennek alapfeltétele pedig az állam megerôsödése, hiszen tartós együttmúködés csak egyenlô felek között képzelhetô el, azaz

- egy gyenge állam nem tud kooperatív környezetet kialakítani,

- csakis egy hatékony és erôs állam képes a magánszektort „rávenni” a tartós kooperálásra.

Figyelembe kell venni azt is, hogy az állam megerôsödését megalapozó strukturális reformok esetében rövid távon a költségek meghaladják a hasznokat, de hosszabb távon a jótékony hatások kerülnek túlsúlyba. ${ }^{7}$

\section{2. ábra: A kooperatív állami múködés kialakitásának lépései}

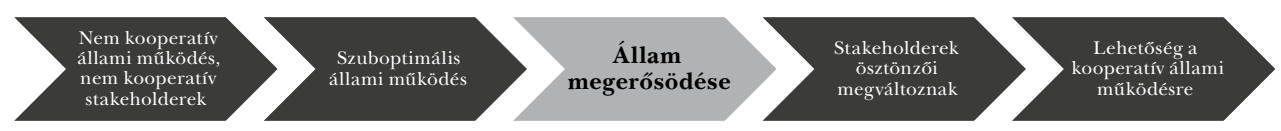

Forrás: Saját szerkesztés 
Jelen tanulmány azt járja körül, hogy az évtized eleje óta meghozott állami intézkedések miképp segítették elố a magyar állam megerôsödését, azaz miképp alapozták meg, hogy a magyar állam el tudjon mozdulni a kooperatív múködés irányába. A szerzók szándéka szerint jelen írást olyan elemzések követik majd, amelyek a jól irányított állam kiépítésének második szakaszára fókuszálnak, vagyis bemutatják, hogy mely területeken érhetố tetten a kooperatív állami múködés térnyerése.

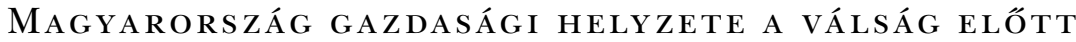

A magas adósság és a sérülékeny finanszírozás miatt Magyarország gyenge növekedési potenciállal és komoly makrogazdasági egyensúlytalanságban érkezett meg a válság elôszobájába. Pedig az évezred elején a magyar gazdaság mutatói régiós összevetésben alapvetôen jók voltak: a folyó fizetési mérleg egyenlege nem lógott ki a környezô országok átlagából, az államadósság ugyan magasabb volt a visegrádi átlagnál, de a kisebb államháztartási hiány miatt kedvezôek voltak a kilátások. Az infláció a régiós átlagnál enyhén magasabb volt, de ennek megfelelốen a gazdaság is dinamikusabban nôtt, mint a kelet-közép-európai térségben.

A 2000-es években ugyanakkor olyan makrogazdasági folyamatok zajlottak le Magyarországon, amelyek régiós viszonylatban éllovasból sereghajtóvá tették a magyar gazdaságot (Matolcsy, 2008), és bebizonyították, hogy az egyensúly megbomlása a teljes gazdaságot fenntarthatatlan pályára tereli.

1. A gazdasági problémák kiindulópontja az elhibázott és felelôtlen költségvetési politika volt, amint azt Baksay-Palotai (2017) is taglalja. Régiós összevetésben kiemelkedô volt a költségvetés hiánya, az állam sokat költött szociális transzferekre, és keveset produktív célokra (a költségvetési kiadások több mint ötödét tették ki a nyugdíjkiadások). A magyar állam évről évre az adott évi gazdasági teljesítményének 6-8 százalékával többet költött, mint amennyi bevétele volt. Ezt a hiányzó összeget elsődlegesen külsố hitelfelvételbôl kellett finanszírozni, aminek következtében a hiány magas szinten ragadása az államadósság érdemi emelkedését okozta. A magyar államadósság 2002-ben a GDP 55 százaléka volt, 2007-re 65 százalék fölé emelkedett a ráta, 2010-ben pedig elérte a GDP 80 százalékát. Nemcsak az államadósság abszolút értéke emelkedett meg jelentôsen, hanem az adósság szerkezete is kedvezôtlen irányba változott (magas deviza- és külföldi adósság).

2. Az egyensúly megbomlása a gazdaság többi területén is éreztette hatását, melyek közül kiemelkedôen fontos volt a munkaerôpiac. A válságot megelôzố évtizedben ugyan növekedésnek indult, de regionális összevetésben így is alacsony maradt az aktivitási ráta. Magyarországon a 15-64 éves korosztály alig több, mint 60 százaléka volt jelen a munkaerópiacon, míg az EU-15-ök átlaga meghaladta a 70 százalékot, és Csehország is nagyjából ilyen munkaerôpiaci aktivitást tudott felmutatni. Mindebben egyértelmúen tetten érhetố az állam felelôssége, hiszen az alacsony foglalkoztatáshoz a munkát terhelố adók magas szintje és kedvezôtlen szerkezete, illetve a szociális transzferek rendszere is hozzájárult. Egy átlagkeresetú egyedülálló munkavállaló esetén a teljes adóterhelés, azaz az adóék 2007-ben meghaladta az 50 százalékot, amelynek két- 
harmadát a munkaadói és munkavállalói járulékok tették ki. Az OECD-országok közül ennél magasabb adóék csak Belgiumban volt érvényben, miközben a cseh, a lengyel érték enyhén 40 százalék feletti, a szlovák pedig 40 százalék alatti volt.

3. A költségvetési hiány növekvô külsố eladósodottsághoz vezetett, miközben a béremelés és a lakosságnak juttatott transzferek a lakosság túlzott mértékú fogyasztásához és így alacsonyabb megtakarításához vezetett. A megugró hiány és csökkenô megtakarítás mellett nôtt a folyó mérleg hiánya, ami egyre nagyobb mértékú külsô eladósodást okozott. Az állam finanszírozási igénye 2002 és 2006 között évrôl évre a GDP 7-8 százalékát tette ki, miközben a lakossági megtakarítások sosem haladták meg a GDP 2 százalékát.

4. Komoly veszélyeztetettséget jelentett, hogy a válság kitöréséig a lakossági hitelek gyors ütemben növekedtek, a háztartási szektor hitelállománya a rendelkezésre álló jövedelem arányában megközelítette a 80 százalékos szintet, miközben a régiós partnerországok ennél 20 százalékponttal alacsonyabb értékeket mutattak. Különösen problémás volt, hogy a hitelfelvétel a devizahitelek irányába tolódott el, a háztartások nyitott devizapozíciója 2008-ra megközelítette a GDP 20 százalékát, míg 2000-ben a magyar családok még nettó megtakarítók voltak a GDP több mint 5 százaléka erejéig.

5. Mindez magas és a régió átlagát érdemben meghaladó inflációval párosult, amit érdemi részben az adóemelések magyaráztak. A fiskális fegyelem lazulása miatt a monetáris politika szigorú volt, ami magas reálkamatokat eredményezett. Mindez erôteljesen támogatta a devizahitelezés felfutását (lásd fenn).

A válság elôtti évek fenntarthatatlan fiskális és monetáris folyamataiból stabilitási és versenyképességi probléma nôtt ki, ennek következményeként Magyarország nem volt képes kiaknázni a 2004-es európai uniós csatlakozásból adódó lehetôségeket: a magyar növekedési adatok regionális összevetésben visszafogottak maradtak, a gazdaság dualitása - a kis- és középvállalati szektor nagyvállalatokétól érdemben elmaradó termelékenysége - a felzárkózás alapvetô korlátjává vált.

A magas kiadások magas adókulcsokat tettek szükségessé, az OECD országai közül Magyarországon volt a második legmagasabb az átlagos adóék. ${ }^{8}$ A magas munkát terhelő adók a nagyvonalú szociális rendszerrel párosulva a munkavállalás ellenösztönzôi voltak, ami azt eredményezte, hogy 2003-tól fokozatosan emelkedett hazánkban a munkanélküliség, és régiós összevetésben a legalacsonyabb hazai munkanélküliségi ráta 2008-2009-re a második legmagasabbra emelkedett. Mindeközben a növekvô eladósodásból finanszírozott, fogyasztásvezérelt növekedés elfedte a strukturális problémákat, az adósságspirál kialakulását pedig elősegítette, hogy a 2011 előtt hatályos magyar Alkotmány nem tartalmazott közpénzügyi fejezetet, azaz nem volt olyan alkotmányos szabály, ami korlátozta volna az állam túlzott eladósodását.

\section{A MAGYAR ÁLLAMPÉNZÜGYEK MEGERÓSÍTÉSE}

A gazdasági válság begyúrúzésekor, 2007-2009-ben fiskális kiigazítás kezdődött, és ezzel párhuzamosan a növekedés is visszaesett. A válság és a megszorítás együtt jelentôs recesszióhoz vezetett, miközben Magyarország többszörös problémával szembesült: 
Kolozsi Pál Péter - Lentner Csaba - Parragh Bianka: Közpénzügyi megújulás és...

egyszerre kellett stabilizálni egyensúlyi mutatóit, adósságpályáját, és javítani a növekedés strukturális feltételeit. Ezen kihívások kezelése csak a nem konvencionális gazdaságpolitikai eszköztár bevonásával volt elképzelhető (Matolcsy-Palotai, 2016).

Az Alaptörvény adósságszabálya mint a magyar gazdaságpolitika egészét átható norma

Az Alaptörvényt 2011 áprilisában fogadta el az Országgyúlés, ezzel új fejezet kezdôdött - többek között - a közpénzügyi gazdálkodás tekintetében is Magyarországon, megalapozva a közpénzügyi rendszer egészének megújulását. Jelen elemzés szempontjából az Alaptörvény alábbi kitételei (amelyek együttesen az adósságszabály alapját alkotják) tekinthetók kiemelten fontosnak: ${ }^{9}$

„36. cikk (4) Az Országgyúlés nem fogadhat el olyan központi költségvetésrôl szóló törvényt, amelynek eredményeképpen az államadósság meghaladná a teljes hazai össztermék felét.

(5) Mindaddig, amíg az államadósság a teljes hazai össztermék felét meghaladja, az Országgyúlés csak olyan központi költségvetésrôl szóló törvényt fogadhat el, amely az államadósság a teljes hazai össztermékhez viszonyított arányának csökkentését tartalmazza.

(6) A (4) és (5) bekezdésben foglaltaktól csak különleges jogrend idején, az azt kiváltó körülmények okozta következmények enyhítéséhez szükséges mértékben, vagy a nemzetgazdaság tartós és jelentôs visszaesése esetén, a nemzetgazdasági egyensúly helyreállításához szükséges mértékben lehet eltérni."

Az alkotmányos szintre emelt adósságszabály a gazdaságpolitika egészét átható elôírás, hiszen a GDP-arányos államadósság csak abban az esetben tud fenntartható módon csökkenni, amennyiben a gazdaságpolitika minden ága ezt tekinti céljának. A GDP-arányos adósság csökkenéséhez az alábbiakra van szükség:

- egyensúlyban, egyensúly közelében lévô központi költségvetés, amely feltételezi az adórendszer teljes átalakítását és a munkaerôpiaci aktivitás érdemi növelését;

- egyensúlyban, egyensúly közelében levô társadalombiztosítás és önkormányzati rendszer, hiszen ezek nélkül a központi költségvetés sem tud fenntartható pályán maradni;

- hatékony és szabályos közpénzfelhasználást, illetve közvagyonhasználatot garantáló közpénzügyi ellenốrzési rendszer, a közpénzek és a közvagyon pazarló felhasználása, használata ugyanis már rövid távon is költségvetési hiányt szül, növelve az államadósságot;

- alacsony infláció, hiszen magas infláció magas kamatokat, és így magas állami kamatkiadásokat és az államadósság drága finanszírozását jelenti, illetve növekedéstámogató monetáris politika, amely ugyancsak elősegíti a GDP-arányos államadósság csökkentését;

- versenyképes gazdaság, amelybôl magas növekedési ütem adódik, hisz ez növeli az adósságmutató nevezójét, és így ceteris paribus csökkenti az adósságrátát.

A továbbiakban az Alaptörvény közpénzügyi elôírásaiból levezethetô, a 2010 utáni megújulási idôszak legfontosabb magyar gazdaságpolitikai intézkedéseit mutatjuk be vázlatosan. ${ }^{10}$ 
A magyar közpénzügyek stabilizálása

\section{Költségvetési folyamatok, fiskális fordulat}

A magyar közpénzügyi helyzet válság elôtti romlásának egyik legegyértelmúbb jele a költségvetési deficit megugrása és magas szinten való stabilizálódása volt. Ennek következménye volt az is, hogy Magyarország 2004 és 2013 között az EU túlzottdeficit-eljárása alatt állt. Az állampénzügyek rendbetétele 2010-2011-ben kezdôdött el, amikor az akkor érvényes európai uniós módszertan szerint számított költségvetési többlet a GDP 4 százalékára ugrott. ${ }^{11}$ 2012-t követően a költségvetés hiánya minden EU-kompatibilis mutatószám szerint a 3 százalékos GDP-arányos érték alatt maradt. A hiány csökkenésében szerepet játszott az elsôdleges (kamategyenleget nem tartalmazó) egyenleg javulása, illetve a nettó kamatkiadások 2013-at követô csökkenése is.

3. ábra: Költségvetési egyenleg alakulása (2000-2016)

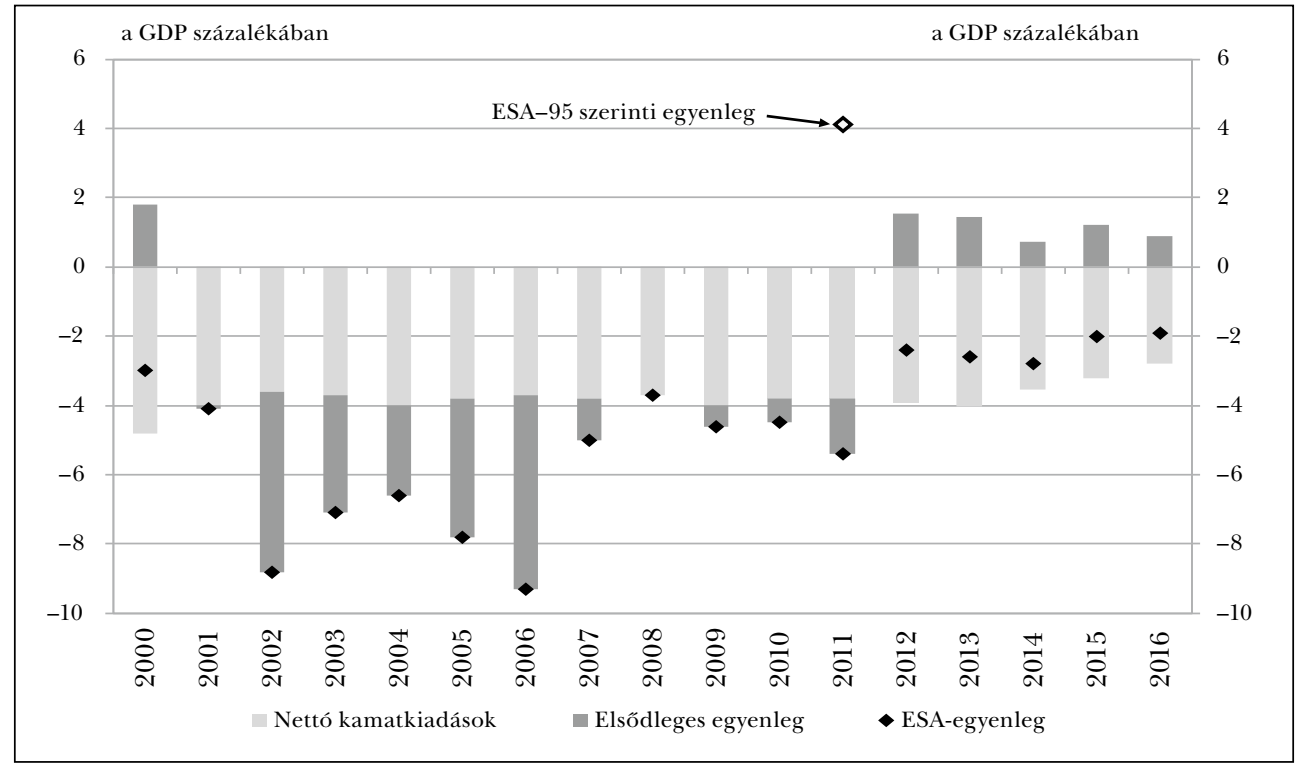

Forrás: Matolcsy, $2017 b$

A magyar fiskális egyensúly javulása nemzetközi összevetésben is kiemelkedô volt, a válságot követốn a magyar költségvetés egyenlege mutatta a legnagyobb javulást az EU-tagállamok között. Magyarországon 2003 és 2007 között a fiskális deficit a GDP 7 százaléka körül alakult, amelyhez hasonló hiányt csak Görögországban lehetett látni, de 2014-2015-ben a magyar hiány 2 százalék közelébe csökkent, ami 5 százalékpontos javulásnak felelt meg - szemben a második legnagyobb javulást mutató Németországgal, ahol a javulás kevesebb mint 3 százalékpontos volt. 
Kolozsi Pál Péter - Lentner Csaba - Parragh Bianka: Közpénzügyi megújulás és...

A 2010-et követôen a költségvetést érintô legfontosabb fiskális és egyéb reformokat a 2. táblázat mutatja be.

\section{2. táblázat: Reformintézkedések 2010 után}

\begin{tabular}{|c|c|c|c|}
\hline Adóreform & Kiadáscsökkentés & Adósságkezelés & Egyéb intézkedések \\
\hline $\begin{array}{l}\text { Élőmunkát terheló } \\
\text { adók csökkentése } \\
\text { Egykulcsos szja beve- } \\
\text { zetése } \\
\text { Családi kedvezmény } \\
\text { Munkahelyvédelmi } \\
\text { Akcióterv } \\
\text { Fogyasztási és forgalmi } \\
\text { adók növelése } \\
\text { Extraprofit adóztatása }\end{array}$ & $\begin{array}{l}\text { Széll Kálmán Terv } \\
\text { Rokkantnyugdíjak } \\
\text { felülvizsgálata } \\
\text { Korhatár alatti nyug- } \\
\text { díj szigorítása } \\
\text { Munkanélküli-támo- } \\
\text { gatás rövidítése }\end{array}$ & $\begin{array}{l}\text { Államadósság tartós } \\
\text { csökkentése } \\
\text { Devizaarány mér- } \\
\text { séklése } \\
\text { Belföldi befektetooi } \\
\text { bázis erôsítése } \\
\text { Átlagos futamidố } \\
\text { növelése }\end{array}$ & $\begin{array}{l}\text { Közmunkaprogram } \\
\text { Devizahitelek kiveze- } \\
\text { tése (forintosítás) } \\
\text { Magánnyugdíjrend- } \\
\text { szer reformja }\end{array}$ \\
\hline
\end{tabular}

Forrás: Matolcsy, $2017 a$

Az intézkedések közül külön is indokolt kiemelni az adóreformot, melynek egyik ikonikus lépése volt a személyijövedelemadó-rendszer átalakítása, ami összességében a GDP 2,5 százalékának megfelelô mértékben csökkentette az adóterhelést. ${ }^{12}$ Az egykulcsos szja 2011-es bevezetését követően a magyar adóék a 2009-ben mért csaknem 60 százalékos szintrôl 50 százalék alá mérséklődött, amivel a hazai adórendszer nemzetközi lemaradása is érdemben mérséklôdött (Varga, 2017a).

\section{4. ábra: Az szja-rendszer átalakitása}

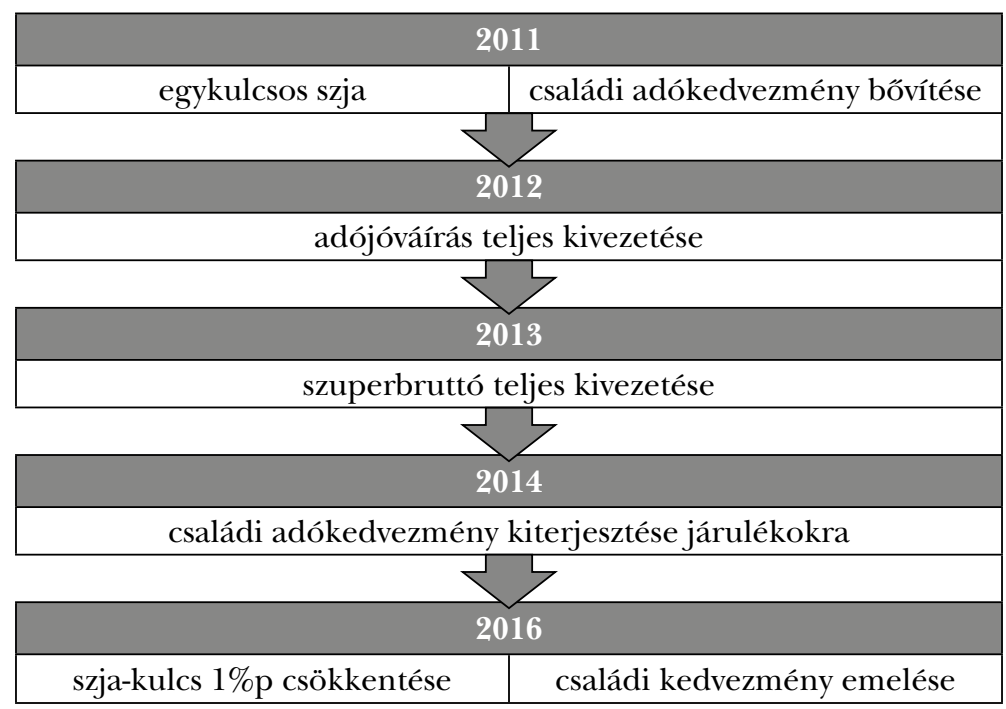

Forrás: Matolcsy, $2017 a$ 
A munkát terhelő adókat fogyasztási adók váltották fel, az átlagbér átlagos szjakulcsa a 2009-es több mint 20 százalékos szintrôl 2016-ra 15 százalékra mérséklődött, amivel Magyarország az európai uniós átlagérték alá került. Új alapokra került a magyar adórendszer: a munkát és a tôkét terhelô adók csökkentek, a fogyasztást terhelô adókból és a különadókból származó bevételek emelkedtek (Palotai, 2017). Az adórendszer egyszerre lett fogyasztásközpontú és teljesítménycentrikus: megéri többet dolgozni és teljesíteni. A különadók érdemben segítették a költségvetést, ezek a bevételek 2013-ban a GDP 2 százalékát tették ki, és 2016-ban is csaknem 1,5 százalékát. A különadók közül 2010-2012-ben a pénzügyi szervezetek különadója (bankadó) és az energiaszektor jövedelemadója volt a domináns, 2013-at követôen pedig a pénzügyi tranzakciós illeték lett a legjelentôsebb tétel.

\section{5. ábra: A 2010 óta végrehajtott adóváltozások kumulált statikus költségvetési hatása}

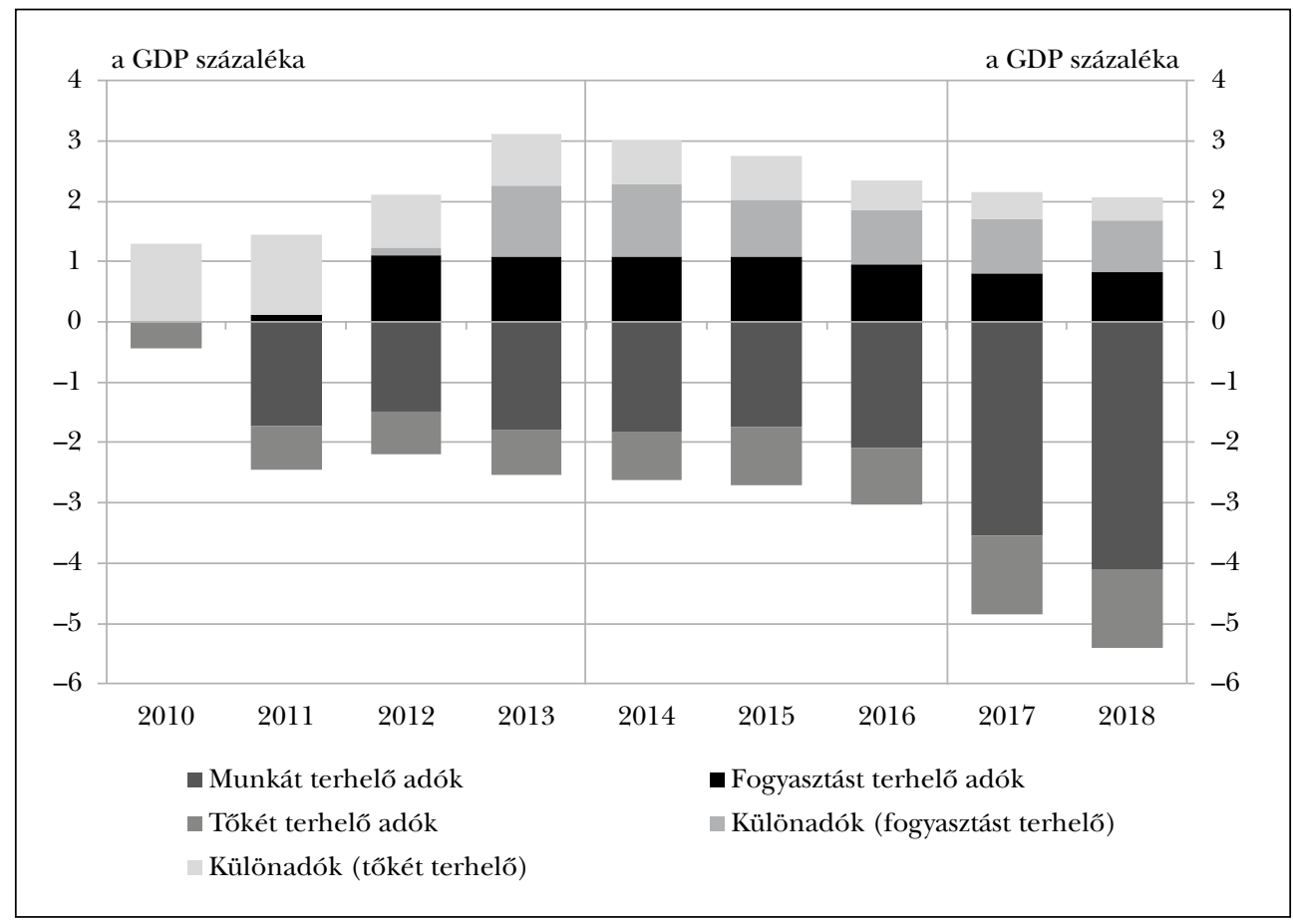

Forrás: Palotai, 2017

\section{Önkormányzati konszolidáció}

Az önkormányzati adósság újratermelődésének elkerülése nemzetgazdasági érdek, miközben az önkormányzatok pénzügyi egyensúlyi helyzete 2007 és 2010 között jelentôsen romlott, a pénzügyi kockázatok fokozódtak. ${ }^{13}$ Az önkormányzatok pénzügyi kapacitásaikat meghaladó mértékú kötelezettséget vállaltak, ezért a központi adósságrendezés elkerülhetetlenné vált, hiszen az önkormányzatok tömeges csôdje belátha- 
tatlan államháztartási és társadalmi problémákat okozott volna. A kormányzat az önkormányzatok adósságrendezésére három lépcsóben kerített sort:

- Az állam elsô lépésként az 5 ezer fó alatti települések adósságkonszolidációja keretében 1710 település adósságát vállalta át.

- Az adósságkonszolidáció második lépésében az állam az 5 ezer fó lakosságszámot meghaladó települések települési önkormányzatának 2012 végén fennálló adósságállománya és ezen adósságnak az átvállalás idôpontjáig számított járulékai összegét részben átvállalta.

- A települési önkormányzatok konszolidálásának utolsó fázisára 2014 tavaszán került sor, amikor az 5 ezer fónél nagyobb helyhatóságok megmaradt adósságállományát is átvállalta az állam. Az adósságkonszolidáció összköltsége több mint 1300 milliárd forintot tett ki.

Rögzítésre került az is, hogy a helyi önkormányzat csak olyan gazdálkodó szervezetben vehet részt, amelyben felelôssége nem haladja meg vagyoni hozzájárulásának mértékét, illetve a helyi önkormányzat vállalkozási tevékenysége a kötelezô feladatainak ellátását nem veszélyeztetheti. 2012. január 1-jétôl több korlátozás érinti a helyi önkormányzatok adósságot keletkeztetô ügyleteit (hitelfelvétel, értékpapír kibocsátása). Ezeket a szabályokat a stabilitási törvény tartalmazza. Az önkormányzat adósságot keletkeztetô ügyletet - szúk körú kivétellel - érvényesen csak a kormány elôzetes hozzájárulásával köthet. Ugyancsak az önkormányzati szektor pénzügyeinek stabilizálódását szolgálta, hogy 2013-tól az önkormányzati költségvetésekben nem tervezhetô múködési hiány. A megyei intézmények, valamint a Fôvárosi Önkormányzat fenntartásában álló egészségügyi intézmények 2012. január 1-jével, a települési önkormányzatok által fenntartott kórházak pedig 2012. május 1-jétól állami fenntartásba kerültek.

\section{Társadalombiztosítási rendszer reformja}

Magyarország 2010 végére azzal a helyzettel szembesült, hogy a kötelezô magánnyugdíjpénztárak által okozott költségvetési hiány egyre jelentôsebb lett, miközben az európai uniós költségvetési hiánycélt tartani kellett. A kormányzati válasz az volt, hogy megszúnt a magánpénztárak feletti „állami védôernyô”, aminek következtében a pénztártagok nagy többsége visszalépett az állami nyugdíjrendszerbe. Az átalakításra mindenekelôtt azért volt szükség, mert a magánnyugdíjpénztári tagok után fizetendô nyugdíjjárulék mintegy negyede a pénztárakba áramlott, így a felosztó-kirovó rendszer lényegébôl adódóan, a nyugdíjkiadások fedezetét képező folyó bevételek jelentôsen lecsökkentek, az így keletkezett hiányt pedig a költségvetésnek kellett kipótolnia. Ez a mechanizmus automatikusan vezetett az államadósság emelkedéséhez abban a szakaszban, amíg a pénztártagok nyugdíjba nem mentek. ${ }^{14} \mathrm{Az}$ állami nyugdíjrendszer fenntarthatóságának kérdése az átalakítás után is releváns maradt, amivel kapcsolatban demográfiai és foglalkoztatáspolitikai tényezókre is figyelemmel kell lenni, miközben kihívást jelent, hogy hazánkban igen magas az alacsony keresetú munkavállalók aránya. A megoldás a gyermekvállalás ösztönzése és a foglalkoztatás növelése lehet, amire az utóbbi években számos kormányzati intézkedés született. 
A tb-rendszer másik pillérét alkotó egészségügy mindenekeloott az elérhetô munkaerô mennyiségén és minôségén keresztül befolyásolja egy ország gazdasági teljesítôképességét a munkában eltöltött aktív idôre és a munkaerô termelékenységére kifejtett hatás révén. A Semmelweis Tervben megfogalmazott koncepció - szervesen kapcsolódva az Új Széchenyi Tervhez - az egészségügy válságból való kilábalása és újjáépítése érdekében a forrásbevonást és a nagyobb állami felelôsségvállalást helyezte a fókuszba.

- A Semmelweis Terv az állami egészségszervezési intézményrendszer kiépítésével a betegútszervezésen és a funkcionális integráción keresztül célozta az ágazat hatékonyságának erőforrás-reallokáción keresztüli javítását.

- Az egészségügyi közkiadások reálértékének fokozatos növelése útján lehetôség nyílik a hibás és káros finanszírozási ösztönzôk tompítására és kiiktatására, továbbá a szakképzett munkaerô megtartására. A Semmelweis Terv a gazdaságfejlesztési stratégia részeként az „egészségügyi ágazatra nem mint a közpénzek mértéktelen fogyasztójára, hanem mint a gazdaság egy fontos potenciális húzóágazatára tekint”.

- Az egészségügyi bérfejlesztés, az alapellátás finanszírozásának 70 százalékos emelkedése, a kórházi adósságrendezés és az adósság hosszú távú csökkentését célzó strukturális változtatások hozzájárulnak az egészségügy fenntartható múködéséhez. A modernizálásában egyaránt döntô jelentôsége lehet a közhiteles adatok, folyamatok kontrollálásának, illetve a betegek érdekeit, a betegbiztonságot az ellátórendszer érdekeivel szemben előtérbe helyezô megújulásnak. Kulcsfontosságú a szabad szellemi foglalkozású orvoslás, az orvoslás presztízsének visszaállítása, a magánforrások ágazatba történô bevonása.

\section{Közpénzügyi ellenôrzés megújítása ${ }^{15}$}

Az Alaptörvény hatálybalépésével közjogi értelemben új idôszámítás kezdôdött a közpénzügyi fegyelem és ellenőrzés tekintetében is. Az Alaptörvény közpénzügyi fejezettel bôvült ki, amely több szigorú szabályt is tartalmaz a közpénzügyi gazdálkodással kapcsolatban (lásd korábban).

- Az Alaptörvény elfogadását követôen az Állami Számvevôszékrôl szóló 2011. évi LXVI. törvény volt az elsố sarkalatos törvény, amelyet az Országgyúlés elfogadott. A 2011. július 1-jétôl hatályos új szabályozási keret azt a célt szolgálja, hogy a Számvevôszék eredményesebben múködjön, és az eddigieknél is hatékonyabban tudjon fellépni az adófizetôk pénzének felhasználása és a nemzet vagyonának védelme érdekében. Az ÁSZ az új törvény alapján a magyar demokratikus állammúködést biztosító gazdasági fékek és ellensúlyok rendszerének egyik legjelentôsebb eleme. Az új jogszabály számos fontos változást hozott, hiszen kiszélesítette az ÁSZ ellenôrzési jogosítványait, érezhetôen megerôsítette a szervezet függetlenségét, és a korábbinál is átláthatóbbá tette a számvevôszéki munkát. A törvény széles körú ellenôrzési felhatalmazást ad az Állami Számvevôszéknek, azaz általános szabályként az ÁSZ-nak joga van minden közpénzfelhasználást és közvagyonhasználatot ellenôrizni.

- Az Alaptörvény az alkotmányi jogállással rendelkezô szervek közé emeli, és az Állami Számvevôszékkel, illetve a Magyar Nemzeti Bankkal megegyezô státuszt ad a 
Költségvetési Tanácsnak. A Tanács ereje az Alaptörvényből eredeztethetô, hiszen épp az a feladata, hogy az alkotmányos adósságszabályt érvényesítse, és az ne csak írott szó maradjon. Az Alaptörvény rögzíti, hogy az adósságállomány leszorítása érdekében a Költségvetési Tanács vétójoggal rendelkezik, amivel a magyar jogalkotók kiemelkedô önkorlátozást vállaltak.

Ezen túl számos más törvény is újrakodifikálásra került, ezek közül kiemelkedik a szintén megújított és új alapokra helyezett államháztartási törvény.

\section{Monetáris politikai fordulat}

A Magyar Nemzeti Bank (MNB) 2013-tól a monetáris politikai eszköztár megújításával és széles körú alkalmazásával (Parragh, 2017a) a válság következményeit aktív monetáris politikával enyhíteni kívánó jegybankok sorához csatlakozott, ahol a hagyományos megoldások új megközelítésú intézkedésekkel egészültek ki (Matolcsy-Palotai, 2014). Az MNB törvényben foglalt feladatának megfelelôen több programmal támogatta a gazdaság stabilizálását és a kormányzat gazdaságpolitikai törekvéseit. ${ }^{16}$ Ezek közül a jól irányított állam kialakítása tekintetében az alábbiakat tekintjük a legfontosabbaknak. (A jegybanki intézkedések bemutatása Matolcsy-Palotai, 2016 és Kolozsi, 2017 nyomán történik.)

\section{Kamatcsökkentési ciklusok, monetáris lazítás}

A Monetáris Tanács 2012 és 2016 között a kezdeti 7 százalékos jegybanki alapkamatot 0,9 százalékra csökkentette, három kamatcsökkentési ciklusban, összesen 32 kamatcsökkentési lépéssel, amivel párhuzamosan a hitelek kamatai és a pénzpiaci hozamok is csökkentek. Magyarországon ilyen hosszú ideig tartó lazítási ciklusra és ilyen alacsony nominális kamatszintre még nem volt példa a rendszerváltás óta. A kamatcsökkentési ciklus kezdetén az infláció 6 százalék közelében volt, majd 2013 elejétôl az infláció is érdemben csökkenni kezdett. A 0,9 százalékos alapkamat elérése után az MNB az alapkamat tartósan alacsony szinten tartása mellett kötelezôdött el.

Az alapkamat csökkentése, illetve a monetáris kondíciók lazítása 1. mérsékelte a bankközi és állampapírpiaci kamatokat, 2. támogatta a gazdasági növekedést és az inflációs cél középtávú elérését, 3. csökkentette a hitelterheket, 4. megakadályozta a hitelállomány, a fogyasztás és a beruházás további drasztikus zuhanását. A monetáris kondíciók lazítása miatt 2017-ben 600 milliárd forint, 2013 óta összesen 1600 milliárd forint állami kamatmegtakarítás keletkezett. ${ }^{17}$ A kamatcsökkentések összességében mintegy 1,1 százalékponttal emelték a gazdasági növekedést. ${ }^{18}$

\section{Hitelösztönzó programok bevezetése}

A 2013-as monetáris politikai fordulat egyik elsó intézkedéseként a Magyar Nemzeti Bank célzott hitelezési programot vezetett be annak érdekében, hogy a foglalkoztatási szempontból kiemelkedôen fontos kis- és középvállalati szektorban megálljon a 
6. ábra: A jegybanki alapkamat és a kamatvárakozások alakulása

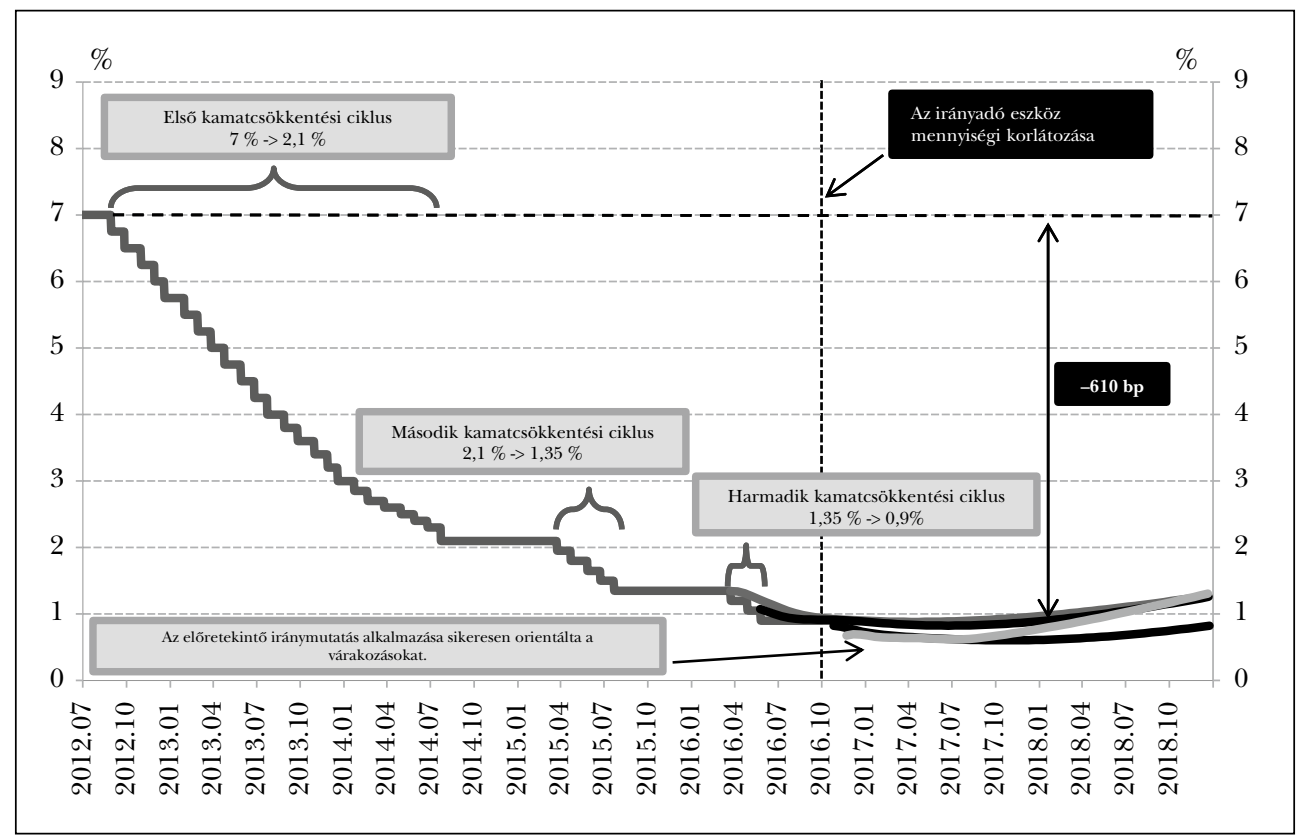

Forrás: Komlóssy - H. Váradi, 2017

hitelállomány csökkenése, és a hitelezési folyamatok normalizálódni tudjanak. A Növekedési Hitelprogram 2016 elejétôl indult harmadik, kivezetô szakasza mellett, 2015 végén a jegybank a piaci hitelezésre való átállást támogató programot is hirdetett, Piaci Hitelprogram néven.

A program egészében mintegy 1700 milliárd forintnyi hitel- és lízingügylet szolgálta új beruházások finanszírozását, az NHP 2013 és 2016 között 2 százalékponttal járulhatott hozzá a gazdasági növekedéshez, a foglalkoztatást pedig mintegy 20 ezer fôvel növelhette. A Piaci Hitelprogram (PHP), az NHP-val közösen érdemben hozzájárul ahhoz, hogy a kkv-hitelezés bôvülése a fenntartható gazdasági növekedéshez szükséges 5-10 százalék közötti sávban alakuljon.

\section{Önfinanszírozási program, a külsô sérülékenység csökkentése}

Az önfinanszírozási program alatt, azaz 2014-2016-ban a megnövekedett forintkibocsátásoknak köszönhetốn a magyar állam mintegy 11 milliárd euró (3400 milliárd forint) devizaadósságot fizetett vissza forintkibocsátásokból. Jelentôsen nôtt a bankok finanszírozásban betöltött szerepe is: 2016-ra a forintállampapírok piacán a külföldi befektetôk helyett a hazai bankrendszer vált a legjelentôsebb tulajdonosi szektorrá. A forintállampapírok piacán 2011 és 2015 között a külföldi befektetôk voltak a legnagyobb szereplôk. 2017 elsố félévének végén ugyanakkor a belföldi szektorok aránya meghaladta a 80 százalékot. A hitelintézetek részesedése 30 százalékról 37 százalékra 
emelkedett, a lakosság részesedése pedig 5 százalék körüli értékről 20 százalék fölé nôtt (a kormányzat 2012-ben stratégiai céllá tette a lakossági állampapír-állomány emelését). Az államadósságon belüli devizaarány a 2014. márciusi 42 százalékról 2016 végére 25 százalékra csökkent, ami nagyságrendileg megegyezett a 2008-as, válság előtti értékekkel (Kolozsi-Hoffmann, 2016; Nagy-Kolozsi, 2017).

\section{Lakossági devizahitelek kivezetése, forintosítás}

A lakosság devizában való eladósodása a magyar gazdaság egyik kiemelt kockázati tényezője volt a 2000-as évek elejétől kezdve. A kockázatok és rendszerszintú problémák indokolták a fedezetlen lakossági devizahitelekkel szembeni állami fellépést (Nagy, 2010; Nagy-Prugberger, 2011), illetve 2014-2015-ben a deviza- és devizaalapú jelzáloghitelek kivezetését is. ${ }^{19} \mathrm{~A}$ devizahitelek kivezetésére két ütemben került sor (elôször a lakossági devizaalapú és deviza-jelzáloghitelek, majd az egyéb lakossági devizahitelek esetében), melyek keretében az MNB összesen mintegy 9,6 milliárd eurót adott el a bankoknak anélkül, hogy a jegybanki tartalékmegfelelés a nemzetközi sztenderdek elvárt szintje alá csökkent volna. A forintosítás és az elszámolás következtében jelentôsen erôsödött Magyarország pénzügyi stabilitása, a kockázatok „kézben tartottsága” érdemben nôtt. A lakossági devizahitelek kivezetése - kiemelten az önfinanszírozási programmal együtt - ezért lehetett az egyik olyan intézkedés, amelyet a hitelminôsítôk a magyar adósság befektetési kategóriába sorolásakor tételesen is a felminôsítés indokaként nevesítettek.

\section{Versenyképességi fordulat}

Egy nemzetgazdaság akkor versenyképes, ha a rendelkezésére álló humán, fizikai és természeti erôforrásait optimálisan hasznosítja a lehetô legmagasabb szintú, de még fenntartható jólét elérése érdekében (MNB, 2017a:11). A versenyképes gazdasághoz nélkülözhetetlenek a szilárd alapok, a stabil makrogazdaság és finanszírozás, az erôs és stabil intézményi háttér, az észszerú és hatékony szabályozás, a minôségi oktatási és egészségügyi ellátás, melyekre építve kialakítható a jól múködô és kiszámítható, beruházásokat és innovációt ösztönzố környezet, elindulhat a tartós gazdasági felzárkózás.

A 2010 óta végrehajtott költségvetési és monetáris politikai fordulatok helyreállították a versenyképesség javításához szükséges makropénzügyi egyensúlyt, és lehetôvé tették 2013-tól az Európai Unió átlagát meghaladó gazdasági növekedés elérését. A költségvetési és jegybanki intézkedések támogatták a gazdasági növekedést ${ }^{20}$ és a foglalkoztatás bôvülését, ${ }^{21}$ és a növekedésfókuszú gazdaságpolitika eredményeit a pénz- és tôkepiac mellett mára a nemzetközi szervezetek és a nagy hitelminôsítôk is elismerik. A gyorsabb és tartós felzárkózáshoz azonban az erôforrások minôségi jellemzőin is javítani kell. A közepesen fejlett gazdasági státuszból való kitöréshez nélkülözhetetlen a felzárkózás felgyorsítása, amelyhez további, a versenyképesség főleg minôségi kritériumaira fókuszáló reformintézkedések szükségesek. A 2010 óta elért 
eredmények megtartása és a tartós felzárkózás felgyorsítása céljából a további hatékonyság- és értékteremtô kapacitás, valamint a termelékenység növelésére való törekvés nélkülözhetetlen (versenyképességi fordulat). Magyarország korábbi régiós vezető versenypozíciójának visszaszerzésére és a közepes fejlettség csapdájából való kitörésre a korábbinál dinamikusabb felzárkózási pálya és növekedési modell további eredményes kiaknázásával és továbbfejlesztésével nyílhat lehetôség.

\section{7. ábra: Versenyképességi reformok és gazdaságpolitikai fordulatok}

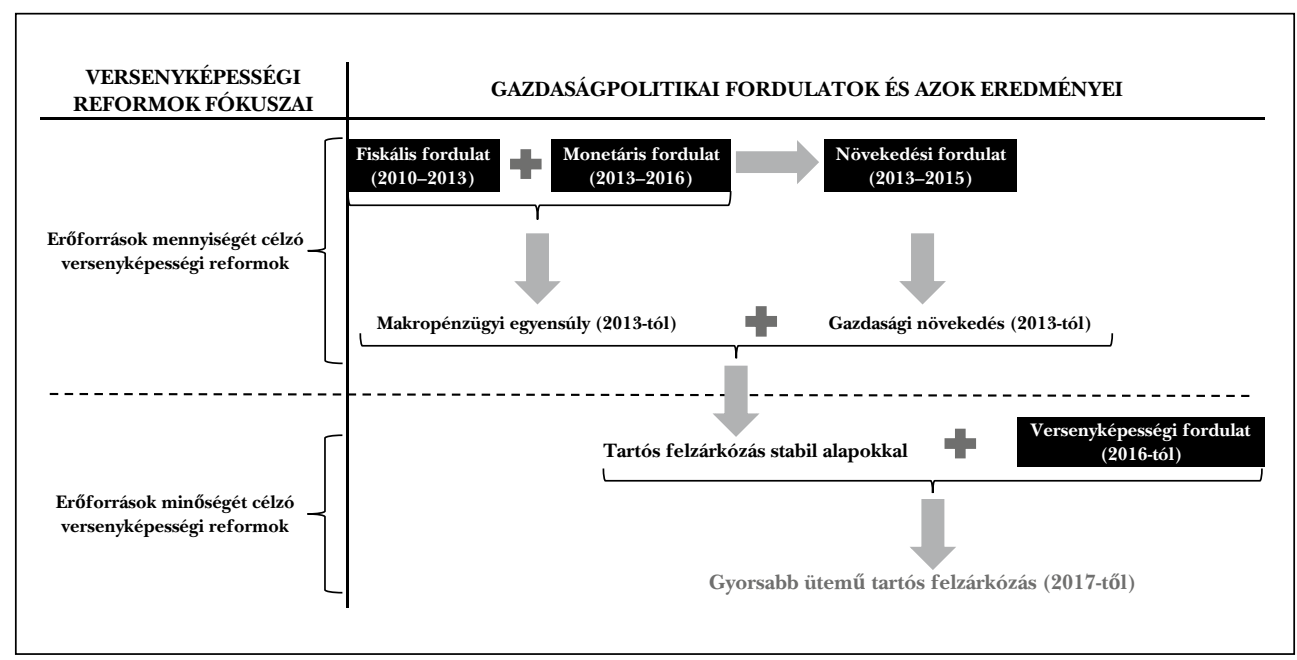

Forrás: Szalai-Kolozsi, 2016

\section{ZÁRÓGONDOLATOK}

Az állampénzügyi pálya fenntarthatatlanságának egyik jó fokmérője az államadósság alakulása. Magyarországon 2010-ig jelentôsen nôtt az államadósság, majd innen csökkenésnek indult az adósságállomány: 80 százalék feletti értékrôl 2016-ra 75 százalék alá csökkent a GDP arányában mért államadósság, ami az adósság „tehetetlensége” miatt jelentős előrelépésnek tekinthető. Mindeközben a devizaadósság teljes államadósságon belüli aránya 50 százalék feletti szintrôl 25 százalékra csökkent, ami azt jelenti, hogy 5 év alatt arányaiban megfelezôdött a devizaadósság, jelentősen csökkentve ezzel a devizakitettséget és az egész magyar gazdaság külsô sérülékenységét. Az adósság csökkenése, illetve a fiskális stabilizáció és a monetáris politikai fordulat együttes hatásaként 2013-ban lehetôvé vált, hogy Magyarország felzárkózása újrainduljon.

Az adósság nemcsak az állam viszonylatában csökkent. A külsố finanszírozási képesség számottevố javulást mutatott Magyarországon, a folyó fizetési mérleg egyenlegének alkalmazkodása hazánkban volt az egyik legnagyobb az Európai Unió tagállamai közül. Mindez azzal járt, hogy Magyarország nettó külsố adóssága a GDP 60 százalékáról 30 százalék közelébe mérséklôdött, miközben a bruttó külsố adósság 120 százalékról 70 százalék közelébe esett. 


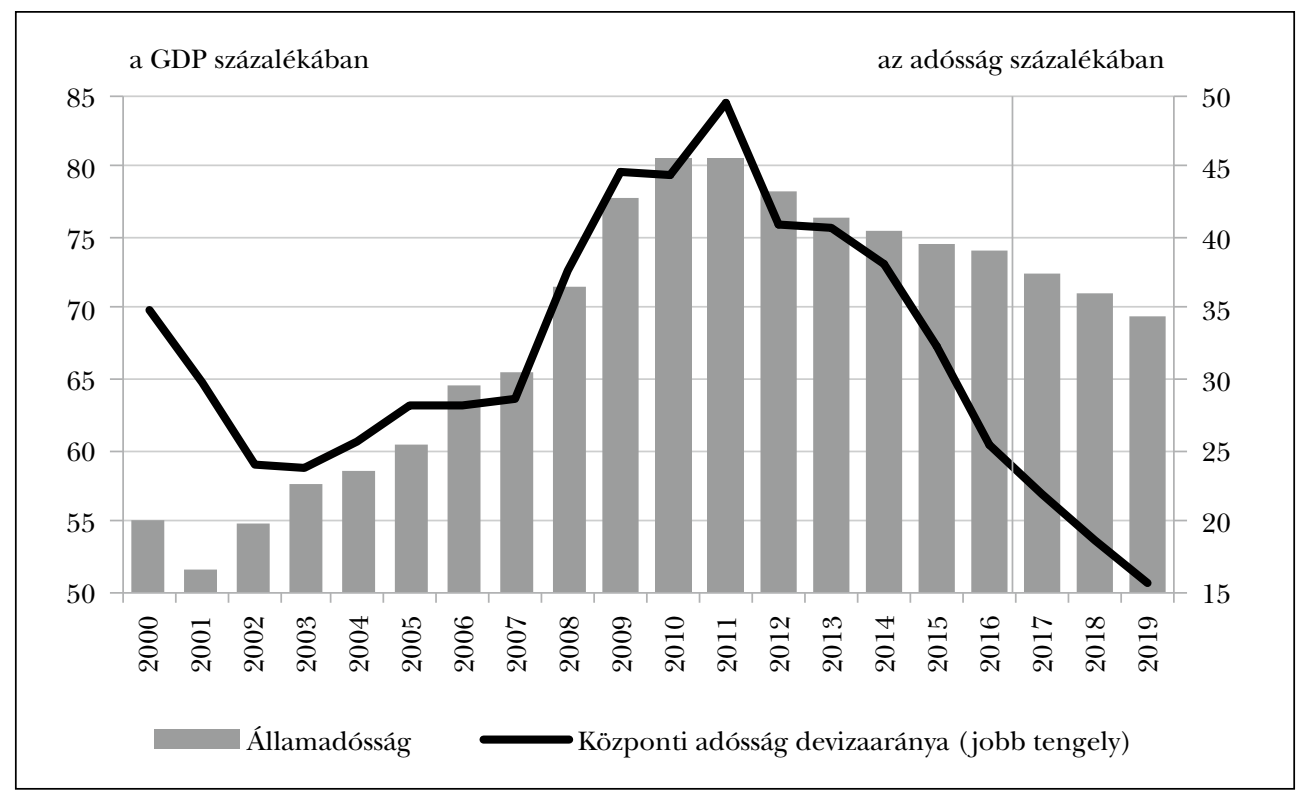

Forrás: $M N B, 2017 b$

A magyar magánszektor adóssága a 2000-es évek elején a legalacsonyabbak közé tartozott, a válság kezdetekor azonban már a középmezônyben állt. A túlzottan eladósodott vállalatok beruházásaik visszafogásával teremtették elô a törlesztéshez szükséges forrásokat, a lakosság átlagos eladósodása pedig ugyan nem volt kirívóan magas, de a devizahitelek miatt kiemelt kockázatot jelentett (Nagy, 2014; 2017). A háztartások és a vállalatok a válságot követôen nettó hiteltörlesztôvé váltak, ami jól példázza, hogy a belsố kereslet, a beruházások visszaesése összefüggött a korábbi adósságfelhalmozással.

Mindeközben a reálgazdaságban sikerült érdemi fordulatot elérni, amiból indokolt kiemelni a munkapiaci fejleményeket. Az aktivitási és foglalkoztatottsági ráta 2014-re csaknem 6 százalékot emelkedett 2007-hez képest, ami egyike volt az Európai Unió legmagasabb növekedési ütemeinek. A válság kezdete óta az aktivitás elsôsorban a jóléti transzferek és az adórendszer átalakítása miatt növekedett, a gazdasági növekedés újraindulását követve elindult a foglalkoztatottak számának bôvülése is.

A fentiek egyértelmúen mutatják, hogy 2010 és kiemelten 2013 óta a magyar állam megerôsödött, a válság elootti idôszak strukturális problémáinak kezelése érdemben elôrehaladt, ami lehetôvé teszi az állami múködés egészét átható modellváltást. Az államnak már van tere olyan intézkedések meghozatalára, amelyek feltételezik mind a megfelelố mozgásteret, mind pedig azt az állami erôt, ami szükséges ahhoz, hogy az állami kooperációra az érintett partnerek részérôl is kooperatív válasz érkezzen. Hangsúlyosan a teljesség igénye nélkül, az utóbbi években hozott intézkedések közül az alábbiakat emeljük ki, mint a jól irányított állam irányába tett fajsúlyos lépések példáit: 
9. ábra: Munkaerópiaci folyamatok (2007-2017)

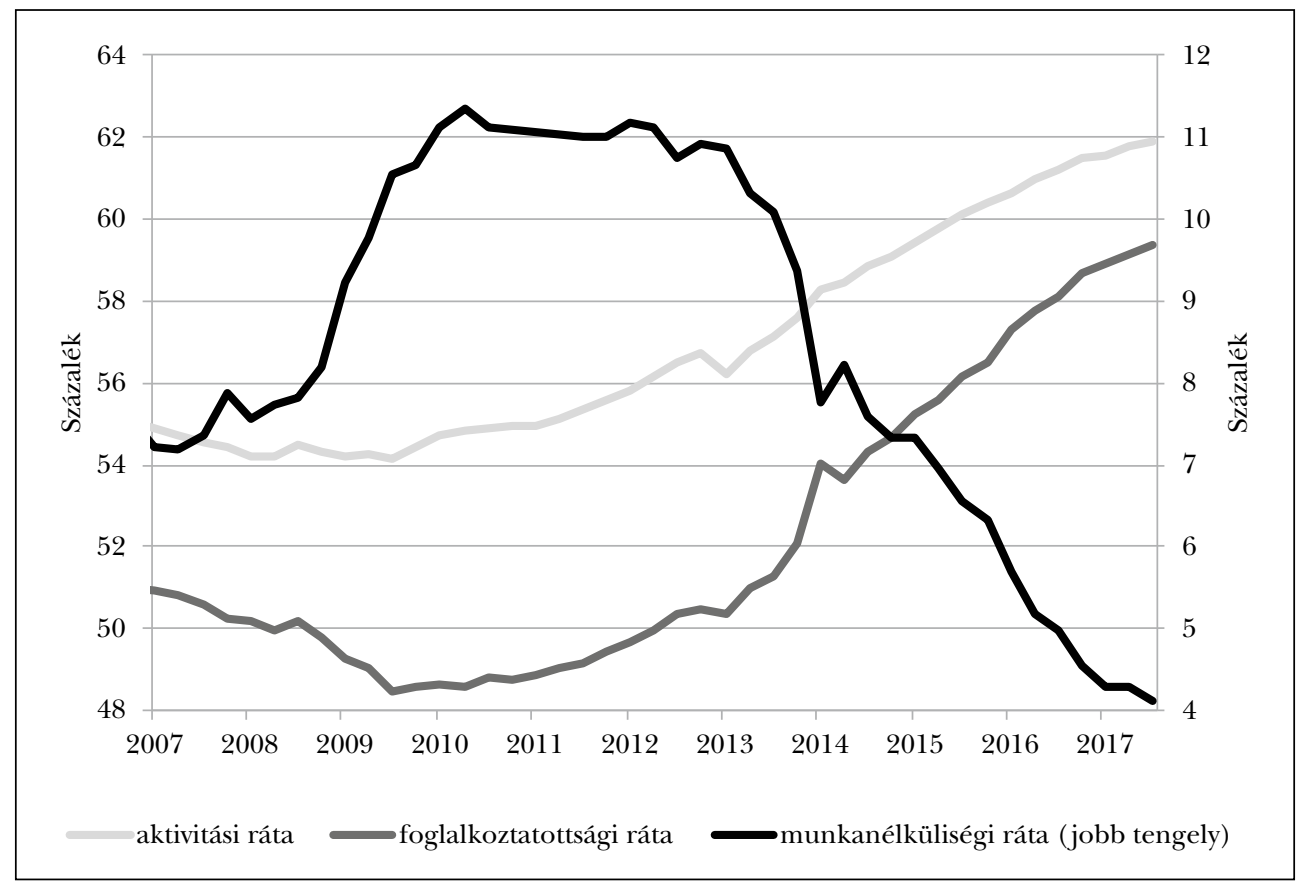

Forrás: $M N B, 2017 b$

- Adócsökkentési politika, ami az adófizetési fegyelem javulásával és az adóbeszedés megújításával (NAV 2.0 koncepció) kiegészülve egyszerre az állam megerôsödésének jele, illetve egy olyan nagy tömegeket érintố kormányzati stratégia, ami az állam és az adófizetốk közötti együttmúködést testesíti meg. Az egykulcsos szja bevezetése elôtt az adóalap a jövedelem 27 százalékkal megnövelt összege volt, az adókulcsok pedig 17, illetve 32 százalékot tettek ki, jelenleg pedig nincs adóalap-korrekció, azaz az adóalap több mint negyedével kisebb, az adókulcs pedig egységesen 15 százalék. Emellett kivezetésre került az adójóváírás rendszere, és jelentôsen bôvült az igénybe vehetố családi adókedvezmény összege. Az adócsökkentés mértékéhez képest ugyanakkor az szja-bevételek mérséklődése kisebb volt: 2010-ben az szja-bevétel a GDP 6,4 százalékát tette ki, 2017-ben pedig 5,2 százalékát, ami nominális értelemben csaknem 200 milliárd forintos emelkedést jelentett. Ezeket az értékeket sok tényezó alakítja, de a tendencia arra utal, hogy javulhatott az adófizetési morál (a fehéredés az áfa esetében még egyértelmúbb volt).

- A monetáris és a fiskális politika közötti konstruktív együttmúködés, ami szakítva a korábbi modellel, nem az egymással versengó és egymást ellentételezô jegybanki és kormányzati múködést, hanem a gazdaságpolitikai célok közös, szinergikus elérését célozza, a jegybanki függetlenség megtartása mellett. A fiskális és a monetáris politika által együttesen érintett gazdaságpolitikai területek, illetve közösen kezelt gazdaságpolitikai kihívások sora hosszú (erról részletesen lásd Matolcsy-Palotai, 2016), de a 
konstruktív kooperáció talán legeklatánsabb példája a lakossági devizahitelek kivezetése (forintosítás) volt, ami nem lett volna megvalósítható a kormány és a jegybank közös és koordinált fellépése nélkül.

- A bankok önkéntes együttmúködésén alapuló jegybanki programok, ahol a programok sikerének alapja, hogy az MNB ösztönzô lépéseire konstruktív és kooperatív banki válasz érkezik. A 2014-ben bevezetett önfinanszírozási program esetében az MNB eszköztár-átalakításai, az ÁKK negatív nettó devizakibocsátása és a bankszektor állampapírpiaci kereslete együttesen és egymást kiegészítve segíti elô az önfinanszírozási koncepció megvalósulását, azaz a külsố sérülékenység csökkentését. A program révén az államadósság devizaaránya 50 százalékról 25 százalékra csökkent. A 2016-ban elindított Piaci Hitelprogram során a pozitív ösztönzést jelentô jegybanki eszközökhöz hozzáférô bankok hitelezési vállalást tesznek, ami definíció szerint egyfajta bankrendszeri-jegybanki kooperációt jelent. A bankok által vállalt hitelezés lehetôvé tette, hogy a kkv-hiteldinamika a korábbi csökkenésból az 5-10 százalékos éves emelkedés felé mozduljon el.

- A közpénzügyi ellenôrzés rendszerének átalakítása, amelyben a megerôsített Állami Számvevőszék a közpénzfelhasználókat „terelő” programokat vezet be és múködtet. Ezt példázza többek között az Integritás projekt, amelynek keretében az Állami Számvevôszék 2011 óta évente felméri a közszféra korrupciós kockázatait és a kezelésükre hivatott kontrollok szintjét. Ugyancsak ehhez a tanácsadói szerephez illeszkednek az ÁSZ jó közpénzügyi gyakorlatok megosztását célzó szemináriumai: a számvevôk az ellenôrzések során nemcsak hibákat tárnak fel, hanem előremutató gazdálkodási megoldásokkal, jó gyakorlatokkal is találkoznak, amiket az ÁSZ A jó példa legyen ragadós! Legjobb gyakorlatok a közpénzek felhasználásánál címú szemináriumsorozat keretében oszt meg az érintettekkel. Az ÁSZ 2011 és 2017 között 17 ilyen szemináriumot szervezett. Szintén egyfajta terelô szerepkört jelent, hogy az Állami Számvevôszék által üzemeltetett hírportál a számvevôszéki munka napi szintû követését teszi lehetôvé, követendô példát állítva a transzparencia tekintetében a közpénzügyi rendszer egésze számára.

Az állam mint speciális gazdasági szerepló és szabályozó, sajátos pozíciójából adódóan érdemben képes hozzájárulni a nemzetgazdasági versenyképesség javításához. A versenyképesség emelése összehangolt, célzott intézkedéscsomagok hatékony alkalmazásával érhetô el, aminek elengedhetetlen feltétele a 2010-tôl véghez vitt állami megújulás, a magyar állam jelen tanulmányban bemutatott megerôsödése. Elôretekintve stratégiai jelentôségú lehet az a szemléletváltás, ami a pozitív ösztönzóket aktívan alkalmazó, partneri együttmúködésre törekvố állami múködéshez vezethet. A megújult állami múködés konkrét példákon keresztüli elemzése további tanulmányok témája lehet.

\section{JEGYZETEK}

1 A globális pénzügyi válságot okozó subprime-válság indokairól lásd Kecskés-Halász, 2010.

2 Thaler örökségének talán legrelevánsabb része azokra a kormányzati intézményekre vonatkozik, amelyeknek az a célja, hogy valamilyen módon abba az irányba terelje, lökje az egyéneket, ami közösségi szinten optimálisabb kimenetet jelent (nudge units).

3 Domokos, 2016 szerint az állam számára a jó kormányzás megvalósításához fokozatos reformok keretében, megbízható és hatékony partnerré válással, kétfázisú stratégia követésével nyílik lehetôség. 
4 A stakeholderszemléletrôl lásd Kecskés, 2011:43.

5 A kooperáció keretében egyrészrôl személyek és szervezetek együtt tevékenykednek egy közös cél elérése érdekében, másrészrôl pedig az érintettek közötti megegyezési gyakorlat is fejlôdik. A tagok közötti együttmúködés lehetôvé teszi a gazdasági és társadalmi haszon növelését.

6 Leegyszerúsítve, játékelméleti megközelítésben, a kérdés gyakorlatilag arra vonatkozik, hogy a kifizetési mátrix mikor válik fogolydilemma-szerúbôl szarvasvadászat-szerúvé. Ennek részletes kifejtésétôl most eltekintünk.

7 A strukturális reformok a gazdaság és társadalom mélyrétegeiben hoznak változást azon keresztül, hogy változtatnak az intézményi kereteken, a jogszabályi környezeten és az intézményes szabályokon. Megváltoztatják a közgondolkodást, ahol az állam megerôsödése egyben a közbizalom megerôsítését hozza magával. Lásd Matolcsy, 2015:232.

8 Adóék alatt a munkát terhelô összes adó- és járulékteher teljes munkaerôköltség arányában mért értékét értve.

9 Lásd az Alaptörvény 36-44. cikkét (közpénzügyi fejezet).

10 Bár e szabályok a szuverén Magyar Országgyúlés jogkörét korlátozták, azonban elengedhetetlenek voltak az új közpénzügyi keret megteremtéséhez. Lásd Kecskés, 2015.

11 Ezt mindenekelőtt a nyugdíjpénztári rendszer átalakítása miatti egyszeri költségvetési bevételek okozták, amit az egyéb módon számolt hiányban nem lehetett így kimutatni.

12 A részletekrôl és következményekrôl lásd Baksay-Csomós, 2015.

13 Az önkormányzatok többségi tulajdonában álló gazdasági társaságok is jelentôs összegú adósságot halmoztak fel úgy, hogy törvényi felhatalmazás hiányában 2011-ig az Állami Számvevôszéknek nem volt jogosultsága az önkormányzati tulajdonban lévố vállalatokat ellenôrizni. Az önkormányzatok pedig nem fordítottak kellô figyelmet a gazdasági társaságaik eladósodásának megelôzésére.

14 Az átalakítás mellett számos egyéb érv is felhozható (alacsony tényleges hozamok, tagokat terhelô magas költségek, hazai tôkepiac várt fejlôdésének elmaradása stb.).

15 A következó összefoglaló alapja Kolozsi, 2014.

16 A jegybanki intézkedésekrôl részletesen lásd Lehmann-Palotai-Virág, 2017.

17 A kapcsolatról részletes lásd Csomós-Kicsák, 2015.

18 Az MNB lazítási politikája 2017 végén már egyértelmúen pozitív visszhangot váltott ki a piaci befektetôk körében. Lásd Eder, 2017.

19 A forintosításra az elsố olyan idôpontban került sor, amikor a jogi háttér és a gazdasági feltételek is adottak voltak (lásd Kolozsi-Banai-Vonnák, 2015).

20 A gazdasági növekedés 2013-tól átlagosan meghaladja a 3 százalékot.

21 A foglalkoztatottak száma 2010 közepén 3,7 millió fố volt, míg 2016-ra 4,4 millió fốre emelkedett.

\section{FELHASZNÁLT IRODALOM}

Baksay Gergely - Csomós Balázs (2014): Az adó- és transzferrendszer 2010 és 2014 közötti változásainak elemzése. Köz-gazdaság, 9. évf., 4. sz., 31-59.

Baksay Gergely - Palotai Dániel (2017): Válságkezelés és gazdasági reformok Magyarországon, $2010-2016$. Közgazdasági Szemle, 64. évf., 7-8. sz., 698-722., https://doi.org/10.18414/ksz.2017.7-8.698.

Csomós Balázs - Kicsák Gergely (2015): A jegybanki programok hosszú távú hatása az államháztartás kamatkiadásaira. Szakmai cikkek, Magyar Nemzeti Bank, augusztus 18.

Domokos László (2016): A jó kormányzás támogatása a számvevôszéki tevékenység megújításán keresztül. PhD-értekezés, Nemzeti Közszolgálati Egyetem, Budapest, 16.

Domokos László et al. (2016a): Szempontok az állammenedzsment megújításához. Fókuszban az állami és önkormányzati tulajdonú gazdasági társaságok irányítása. Pénzügyi Szemle, 61. évf., 2. sz. 185-204.

Domokos, László et al. (2016b): Renewal of Public Management. Contributions of State Audit Office of Hungary to enhance corporate governance of state-owned enterprises. Public Finance Quarterly, Vol. 61, No. 2, 178-198. 


\section{Kolozsi Pál Péter - Lentner Csaba - Parragh Bianka: Közpénzügyi megújulás és...}

Domokos, László - Holman, Magdolna (2017): The Methodological Renewal of the State Audit Office of Hungary in Light of the Protection of Public Funds. Polgári Szemle/Civic Review, Vol. 13, Special Issue, 83-99, https://doi.org/10.24307/psz.2017.0306.

Eder, Marton (2017): Hungary's Central Bank Gets Forceful, and Creative, With QE. Bloomberg, December 12, www.bloombergquint.com/global-economics/2017/12/06/hungary-s-central-bank-gets-forceful-andcreative-with-qe-push.

Jakovác, Katalin - Domokos, László - Németh, Erzsébet (2017): Supporting Good Governance in SAI's Audit Planning. Polgári Szemle/Civic Review, Vol. 13, Special Issue, 64-83, https://doi.org/10.24307/ psz.2017.0305.

Kecskés András (2011): Felelôs társaságirányítás (Corporate Governance). HVG-ORAC, Budapest.

Kecskés, András (2015): Inside and Outside the Province of Jurisprudence. Rechtstheorie, Vol. 46, No. 4, 465-479, https://doi.org/10.3790/rth.46.4.465.

Kecskés András - Halász Vendel (2010): A siker díja vagy a bukás ára? A vállalati vezetôk javadalmazásának elmélete a pénzügyi válság tükrében. Jogtudományi Közlöny, 65. évf., 4. sz., 180-191.

Kolozsi Pál Péter (2014): Államháztartási kontroll. NKE VTKI, Budapest.

Kolozsi Pál Péter (2017): Konstruktív összhang a gazdaságpolitikában - jegybanki programok és a jól irányított állam. Új Magyar Közigazgatás, 10. évf., Különszám.

Kolozsi Pál Péter - Banai Ádám - Vonnák Balázs (2015): A lakossági deviza-jelzáloghitelek kivezetése: idôzítés és keretrendszer. Hitelintézeti Szemle, 14. évf., 3. sz., 60-87.

Kolozsi Pál Péter - Hoffmann Mihály (2016): A külsố sérülékenység csökkentése monetáris politikai eszközökkel. A Magyar Nemzeti Bank jegybanki eszköztárának megújítása (2014-2016). Pénzügyi Szemle, 61. évf., 1. sz., 9-34.

Komlóssy Laura - H. Váradi Balázs (2017): Kamatcsökkentési ciklusok - fokozatos, óvatos lépésekkel jelentôs lazítás. In: A magyar út - célzott jegybanki politika. Szerk. Lehmann Kristóf, Palotai Dániel, Virág Barnabás, Magyar Nemzeti Bank, Budapest.

Lehmann Kristóf - Palotai Dániel - Virág Barnabás (szerk.) (2017): A magyar út - célzott jegybanki politika. Magyar Nemzeti Bank, Budapest.

Lentner, Csaba (2010): A few historic and international aspects of the Hungarian economic crisis and crisis management. Public Finance Quarterly, 55. évf., 3. sz., 581-606.

Lentner Csaba (2014): A magyar önkormányzatok adósságkonszolidációja. Pénzügyi Szemle, 59. évf., 3. sz., 330-344.

Matolcsy György (2008): Éllovasból sereghajtó. Elveszett évek krónikája. Éghajlat Könyvkiadó, Budapest.

Matolcsy György (2015): Egyensúly és növekedés. Kairosz Könyvkiadó, Budapest.

Matolcsy György (2017a): Tíz évvel a válság után, 2007-2017. Elôadás az MKT Vándorgyúlésén. 2017. szeptember 17 .

Matolcsy György (2017b): Versenyképesség, versenyképesség, versenyképesség. Elôadás az MKIK Gazdasági Évnyitóján. 2017. február 28.

Matolcsy György - Palotai Dániel (2014): Növekedés egyensúlytalanságok nélkül. Polgári Szemle, 10. évf., 1-2. sz.

Matolcsy György - Palotai Dániel (2016): A fiskális és a monetáris politika kölcsönhatása Magyarországon az elmúlt másfél évtizedben. Hitelintézeti Szemle, 15. évf., 2. sz., 5-32.

MNB (2017a): Versenyképességi jelentés. Magyar Nemzeti Bank, Budapest.

MNB (2017b): Inflációs jelentés. Magyar Nemzeti Bank, Budapest, 2017. szeptember.

Nagy, Márton - Kolozsi, Pál Péter (2017): The Reduction of External Vulnerability and Easing of Monetary Conditions with a Targeted Non-Conventional Programme: The Self-Financing Programme of the Magyar Nemzeti Bank. Polgári Szemle/Civic Review, Vol. 13, Special Issue, 99-118, https://doi. org/10.24307/psz.2017.0307.

Nagy Zoltán (2010): A gazdasági válság hatása a pénzügyi intézmények és szolgáltatások szabályozására. Publicationes Universitatis Miskolciensis. Sectio Juridica et Politica, Tomus 28., 229-243.

Nagy Zoltán (2014): Az Európai Unió Bíróságának a devizahitelezéssel kapcsolatos ítélkezési gyakorlata fogyasztóvédelmi aspektusból, In: A devizahitelezés nagy kézikönyve. Szerk. Lentner Csaba, Nemzeti Közszolgálati és Tankönyv Kiadó, Budapest, 435-452. 
Nagy Zoltán (2017): Problémafelvetések a pénzügyi fogyasztóvédelem területén. Miskolci Jogi Szemle, 12. évf., Különszám, 391-401.

Nagy Zoltán - Prugberger Tamás (2011): A lakossági hitelezéssel kapcsolatos szabályozási problémák. Competitio, 10. évf., 1. sz., 44-51.

Novoszáth Péter (2014): A társadalombiztosítás pénzügyei. Nemzeti Közszolgálati és Tankönyv Kiadó, Budapest.

Orbán Balázs (2017): Az állam újrafeltalálása. Mandiner, november 6.

Palotai Dániel (2017): Beértek a 2010-2013 közötti adóreform kedvezô hatásai. Portfolio.hu, szeptember 18.

Parragh Bianka (2017a): Monetáris hitviták. A megváltozott jegybanki szerepfelfogás eredményei. Pénzügyi Szemle, 62. évf., 2. sz., 234-250.

Parragh, Bianka (2017b): Competitiveness and Economic Stimulus. New Dimensions and Instruments of Monetary Policy. Polgári Szemle/Civic Review, Vol. 13, Special Issue, 151-166, https://doi.org/10.24307/ psz.2017.0309.

Szalai Ákos - Kolozsi Pál Péter (2016): Mit kell tennünk egy versenyképesebb magyar gazdaságért? Gondolatok a Magyar Nemzeti Bank Versenyképesség és növekedés címú monográfiájával kapcsolatban. Polgári Szemle, 12. évf., 4-6. sz.

Varga József (2017a): A magyarországi adószerkezet átalakításának aktuális kérdései. In: Pénzügy-számvitelstatisztika füzetek II. 2016. Konferenciakötet (Miskolci Egyetem Gazdaságtudományi Kar, 2016. december 1.), szerk. Bozsik Sándor, Miskolci Egyetemi Kiadó, Miskolc, 81-87.

Varga József (2017b): Az adóteher-csökkentés és a gazdaság kifehérítésének pályája Magyarországon 2010 után. Pénzügyi Szemle, 62. évf., 1. sz., 7-20.

Varga, József (2017c): Reducing the Tax Burden and Whitening the Economy in Hungary after 2010. Public Finance Quarterly, Vol. 62, No. 1, 7-21.

Zéman Zoltán (szerk.) (2017): Stratégiai pénzügyi controlling és menedzsment. Akadémiai Kiadó, Budapest.

Zéman Zoltán - Tóth Antal (2015): Az önkormányzatok és közüzemi vállalatok teljesítményértékelése. In: Adózási pénzügytan és államháztartási gazdálkodás. Közpénzügyek és államháztartástan II. Szerk. Lentner Csaba, NKE Szolgáltató Kft., 829-853. 